\author{
Asian Journal of \\ Medical and Biological Research \\ ISSN 2411-4472 (Print) 2412-5571 (Online) \\ www.ebupress.com/journal/ajmbr
}

\title{
Article \\ A study on consumption of iodine by an individual in selected area in Tangail, Bangladesh
}

\author{
Sabina Yeasmin, Najia Kamrul, M. Burhan Uddin* and Md. Fahad Jubayer \\ Department of Food Technology and Rural Industries, Bangladesh Agricultural University, Mymensingh-2202, \\ Bangladesh
}

*Corresponding author: Professor Dr. M. Burhan Uddin, Department of Food Technology and Rural Industries, Bangladesh Agricultural University, Mymensingh-2202, Bangladesh. Mobile: +8801711110509; E-mail: burhan992003@yahoo.com

Received: 07 June 2016/Accepted: 23 June 2016/ Published: 30 June 2016

\begin{abstract}
The purpose of this study was to assess consumption of iodized salt by an individual (g/person/day) in a village of Tangail district and to compute the intake of iodine by an individual ( $\mu \mathrm{g} / \mathrm{person} / \mathrm{day})$ in a village in Tangail district. Vacuum evaporated salt was used for the study. The salt was analyzed for chemical composition and iodine content. Various physico-chemical characteristics of salt were analyzed to determine the moisture content, chloride content (as $\mathrm{NaCl}$ ), water insoluble matter, $\mathrm{pH}$, calcium content, magnesium content, and iodine content. Study was done among 68 families for a period of 35 days. Family member was divided into 4 groups according to their age - below 5 years, 5-9 years, 10-19 years and above 19 years. Male member among the family members was minimum 1 and maximum was 8 . In case of female, minimum number was 1 and maximum number was 7. Among family members, $45.58 \%$ were male and $54.42 \%$ were female consumers. Percentage of salt consumers among Family members below 5 years was $11.81 \%$, in 5-9 years it was $6.94 \%$. Percentage of salt consumer in family members between 10-19 years was $24.54 \%$, and salt consumers percentage in family members above 19 years was $56.71 \%$. By statistical analysis among data, mean value of salt consumption g/ person /day was 12.49, standard deviation was 2.05 and minimum salt consumption among family members was $10.02 \mathrm{~g} /$ person/day and maximum value was $18.47 \mathrm{~g} /$ person/day. Among the family members, mean value of intake of iodine was $399.68 \mu \mathrm{g} / \mathrm{person} /$ day, maximum intake of iodine was 591.04 $\mu \mathrm{g} / \mathrm{person} / \mathrm{day}$ and minimum intake was $320.64 \mu \mathrm{g} /$ person/day. Finding of this study was that, salt consumption rate are satisfactory and intake of iodine by individual in village Chamuria in Tangail district is adequate to avoid Iodine Deficiency Disorder in normal health condition.
\end{abstract}

Keywords: salt; iodine; calcium; magnesium; Bangladesh

\section{Introduction}

Iodine is an essential trace element present in nature. The bioavailability of iodide from iodized salt is only $10 \%$ of the estimated $0.75 \mathrm{mg}$ iodide in iodized salt consumed per day (Edmundson et al., 1999; Abraham, 2006). Iodine is an essential micronutrient for normal growth and development. The human body contains about 15-20 $\mathrm{mg}$ of iodine, of which $70-80 \%$ is concentrated in the thyroid gland. Iodine is primarily obtained through the diet, but it is also a component of some medications (FAO and WHO, 2001). Dietary iodine is converted into the iodide ion in the gut lumen, and $>90 \%$ is rapidly absorbed in the upper small intestine. However, absorption can be reduced by the presence of goitrogens in some foods and by deficiency of other micronutrients, such as selenium or iron. Fifteen percent of ingested iodine is taken up by the thyroid gland within $24 \mathrm{~h}$ of ingestion, and the excess is excreted by the kidneys in urine (EFSA, 2006). Iodine deficiency can be caused by consumption of iodine less salt or less iodine containing salt below the minimum requirement (Diosady et al., 1998). Iodine can be added to salt as potassium iodide, potassium iodide, or, less frequently, sodium iodide. 
Salt is an excellent carrier for iodine, as it is consumed at relatively constant, well-definable levels by all people within a society, independently of socio-economic status. Salt is iodized by the addition of fixed amounts of potassium iodide or iodate, as either a dry solid or an aqueous solution. Iodine deficiency disorders (IDD) are one of the major nutritional problems in Bangladesh. Iodine deficiency affects at all stages of life. To eliminate the iodine deficiency, some countries use iodized capsule/oil or add iodine in drinking water. But the easiest way to control the problem is to use iodized salt, which is universally recognized as the most cost effective strategy in countries where iodine deficiency is wide spread (Bangladesh Gazette, 1989).

Iodine deficiency disorders (IDD) are recognized as a major global public health problem. According to the latest estimates, about 2.5 billion people worldwide (38\% of the world's population) have insufficient iodine intake, of which 313 million are in the South-eastern Asian region that includes Bangladesh. Iodine deficiency is the single most preventable cause of neurological and intellectual impairment (cretinism) in the world. The law stipulates that all salt for human consumption must contain 45-50 parts per million (ppm) of iodine at the time of production and not less than $20 \mathrm{ppm}$ iodine at the time of retail, to ensure a minimum of $15 \mathrm{ppm}$ iodine at the household level (Harun, 2008). To prevent iodine deficiency disorders (IDD) in human, diet must be supplemented with iodine. During the past twenty years there has been a strong effort, lead by the United Nations, to iodize all salt for human consumption (Venkatesh Mannar, 1987). The iodine addition level is important, since too low levels in the diet will have no noticeable benefit, while excessive doses are wasteful, and may actually result in detrimental health effects. Considering these views in mind attempt was undertaken to analyze the physico-chemical properties of iodized salt, to determine the iodine content in a commercial iodized salt as well as to assess consumption of iodized salt by an individual (g/person/day) in a village in Tangail and to compute the intake of iodine by an individual $(\mu \mathrm{g} / \mathrm{person} / \mathrm{day})$ in a village in Tangail.

\section{Materials and Methods}

\subsection{Analysis of iodized salt}

The chemical analysis of salt was carried out in the Ph.D. laboratory of the Department of Food Technology and Rural Industries, Bangladesh Agricultural University, Mymensingh-2202, Bangladesh.

\subsection{Determination of moisture content of salt}

AOAC (2005) method was used to determination of moisture content of salt.

\subsection{Estimation of iodine in iodized salt}

AOAC Official Methods of Analysis. 1984. Section 33, 147.

\subsection{Determination of sodium choloride in iodized salt}

AOAC (2005) method was used to determination of NaCI of salt.

\subsection{Determination of calcium \& magnesium (water soluble)}

$20 \mathrm{~g}$ of salt sample was taken into a $1000 \mathrm{ml}$ volumetric flask. Distilled water was added to the volumetric flask to make the volume to $1000 \mathrm{ml}$. Hence the mother solution was prepared. For magnesium determination $10 \mathrm{ml}$ of mother solution was taken into a $250 \mathrm{ml}$ conical flask and $20-30 \mathrm{ml}$ of distilled water was added. $10 \mathrm{ml}$ buffer solution ( $\mathrm{pH} 10$ ) was added. Then 2-3 drops of Eriochrome Black T as indicator was added. Titrate with $0.01 \mathrm{~N}$ EDTA till the wine red color changes to pure blue or blackish blue (End point). The same procedure was followed with distilled water instead of sample for the blank titration. On the other hand for calcium determination $10 \mathrm{ml}$ of mother solution was added into a $250 \mathrm{ml}$ conical flask \& 20-30 ml distilled water was added to it. $100 \mathrm{~g}$ of calcon mixed indicator was added and Titrate with $0.01 \mathrm{~N}$ EDTA till the green color changes to purple (End point). Same procedure was followed with distilled water instead of sample for the blank titration.

\section{Calculation:}

$\%$ of $\mathrm{Mg}^{++}=\frac{(\mathrm{V} 1-\mathrm{V} 2) \times \mathrm{F} \times 243.1}{\mathrm{M}}$

Where,

$\mathrm{M}=$ mass in $\mathrm{gm}$ of dried sample

$\mathrm{V} 1=$ Volume of EDTA required for Magnesium, $\mathrm{ml}$

$\mathrm{V} 2=$ Volume of EDTA required for Calcium, $\mathrm{ml}$

$\mathrm{F}=$ Factor 
Calculation:

$\%$ of $\mathrm{Ca}^{++}=\frac{\mathrm{V} 2 \times \mathrm{F} \times 400}{\mathrm{M}}$

Where,

$$
\begin{aligned}
M & =\text { mass in gm of dried sample } \\
V 2 & =\text { Volume of EDTA required for Calcium, } \mathrm{ml} \\
\mathrm{F} & =\text { Factor }
\end{aligned}
$$

\subsection{Determination of $\mathrm{pH}$ of iodized salt}

The $\mathrm{pH}$ of the selected samples was determined by the conventional procedure by a $\mathrm{pH}$ meter.

\subsection{Determination of insoluble matter in salt}

AOAC (2005) method was used to determination insoluble Matter in salt.

\subsection{Estimation of potassium iodate solution used for iodized salt}

AOAC (2005) method was used to determination of potassium iodate solution used for salt.

\subsection{Salt intake survey}

The study was conducted in the village chamuria, kalihati. Eighty questionnaires were distributed among the respondents and 68 complete questionnaires were received from them. Survey work are done by taking 68 families which was selected having at least one family members below 5 years, between 5-9 years, 10-19 years and above 19 years. Salt was distributed among family member in plastic pot with a spoon. Initially $2 \mathrm{~kg}$ of salt was supplied to each family in plastic pot. Weight of the salt was taken at an interval of 7 days and continued up to 35 days. Additional salt was supplied if required. During study period it was noted how many members took meals outside by family and how many guests were entertained. Quantitative and Qualitative data were converted into scoring wherever necessary. Data obtained from the respondents were first transferred to a master sheet, then compiled, coded, tabulated and analyzed in accordance with the objectives of the study. Such statistical measures as number and percentage distribution, range, mean and standard deviation were used in describing different variables. For clarity of understanding tables were used in presenting data. The data were entered into computer by using Microsoft Excel spread sheet and SPSS (Statistical Package for Social Sciences) package program.

\section{Results}

\subsection{Physico-chemical analysis of iodized salt}

\subsubsection{Moisture content of iodized salt}

Moisture content of iodized Salt was shown in Table1. In table showed that, by observation, amount of moisture content was found $0.18 \%$ in iodized salt, which is compared with BDS standard 6\%, WFP standard 3\%, China standard $0.1 \%$ and India standard $0.5 \%$.

\subsubsection{Water insoluble matter of iodized salt}

Water insoluble matter of iodized Salt was shown in Table 1. In the table showed that, amount of Water insoluble matter percent by mass in iodized salt was $0.11 \%$ by observation, which is compared with BDS, WFP, China, and India standard $0.1 \%, 0.2 \%, 0.1 \%$ and $0.1 \%$ respectively.

\subsubsection{Chloride content (as Nacl) $\%$ in iodized salt}

Chloride content (as Nacl) \% of iodized salt was shown in Table 1. In the table showed that, by observation, amount of Chloride content (as Nacl)\% in iodized salt was $99.55 \%$ which is compared with BDS, WFP, China, and India standard 97\%, 97\%, 99\% and $98.50 \%$ respectively.

\subsection{4. $\mathrm{pH}$ of iodized salt}

$\mathrm{pH}$ of the samples obtained by analysis was 7.26. In BDS standard it is ranges between 6.4-7.4, in WFP it varies from 6.5-7.5, in China Standard it is 6.5-7.4 and India standard it ranges between 6.6-7.2.

\subsubsection{Iodine, $\mathrm{Mg}$ and $\mathrm{Ca}$ content of iodized salt}

Iodine of the samples obtained by analysis was $32 \mathrm{mg} / \mathrm{kg}$, In BDS standard it is ranges between 20.0-50.0 $\mathrm{mg} / \mathrm{kg}$, in WFP standard and Canada standard it is same to BDS and India it is $30 \mathrm{mg} / \mathrm{kg}$. 
$\mathrm{Mg}$ and Ca content of iodized Salt of the samples were obtained by analysis was $0.00 \%$ and $0.09 \%$ respectively. In different standard it is $0.1 \%$.

\subsection{Salt intake survey results}

\subsubsection{Distribution of respondent by gender}

Distribution of respondent by gender is shown graphically in Figure1.

In this study, 68 family were selected which have total family numbers 432. In which male members were 198 and female members were 234 out of 432 . The mean of male and female was 2.88 and 3.44 respectively. Male member in the family is minimum 1 and maximum 8 . In case of female minimum number 1 and maximum number was 7 . In percentages, $45.58 \%$ of male salt consumers and $54.42 \%$ were female consumers.

\subsubsection{Distribution of respondent by age group}

Distribution of respondent by age group is shown graphically in Figure2.

In this study, 68 family was selected which have total family numbers 432 . Family members are divided into 4 categories according to their age. In case of category, Family members below 5 years was fall into category 1, in category 2 family members 5-9 yrs old were held, family members 10-19 years and family members above 19 years were held into category 3 and category 4 respectively. Sum of category 1, 2, 3, 4 are 51, 30, 106 and 245 respectively. Percentage of salt consumer in family members below 5 years was $11.81 \%$, in family members $5-9$ years, it was $6.94 \%$, percentage of salt consumer in Family members $10-19$ years was $24.54 \%$ and percentage of salt consumer in Family members above 19 years was $56.71 \%$.

\subsubsection{Salt consumption g/person/day}

Salt consumption g/day/person is shown graphically in Figure3.

By statistical analysis among data, the mean value of salt consumption g/ person /day was 12.49 , minimum salt consumption g/person/day among members was 10.02 and maximum consumption was $18.47 \mathrm{~g} /$ person /day among the family members.

\subsubsection{Intake of iodine $\mu \mathrm{g} /$ person /day}

Intake of iodine $\mu \mathrm{g} / \mathrm{person} / \mathrm{day}$ is shown graphically in Figure4.

By statistical analysis among data, the mean value of intake of iodine $\mu \mathrm{g} / \mathrm{person} / \mathrm{day}$ was 399.68 , minimum intake of iodine $\mu \mathrm{g} /$ person/day was 320.68 and maximum intake of iodine $\mu \mathrm{g} /$ person/day was 591.04 among the family members.

Table 1. Parameters of Physico-chemical properties of iodized salt.

\begin{tabular}{llllll}
\hline Parameters & $\begin{array}{l}\text { Observed } \\
\text { value }\end{array}$ & $\begin{array}{l}\text { BDS } \\
\text { (Bangladesh) } \\
\text { standard value }\end{array}$ & $\begin{array}{l}\text { WFP } \\
\text { (World food } \\
\text { program) } \\
\text { standard }\end{array}$ & $\begin{array}{l}\text { China } \\
\text { standard }\end{array}$ & $\begin{array}{l}\text { India } \\
\text { standard }\end{array}$ \\
\hline Moisture percent by mass & 0.18 & 6.0 & 3.0 & 0.1 & 0.5 \\
Water insoluble matter percent by mass & 0.11 & 0.1 & 0.2 & 0.1 & 0.1 \\
Chloride content (as NaCl) & 99.55 & 97.0 & 97.0 & 99.0 & 98.50 \\
pH Range & 7.26 & $6.4-7.4$ & $6.5-7.2$ & $6.5-7.4$ & $6.6-7.2$ \\
Mg & 0.00 & 0.1 & 0.1 & 0.1 & 0.1 \\
Iodine content $\mathrm{mg} / \mathrm{kg}$ & 32 & 20.0 to 50.0 & 20.0 to 50.0 & 20.0 to 50.0 \\
$\mathrm{Ca}$ & 0.09 & 0.1 & 0.1 & 0.1 & 30 \\
\hline
\end{tabular}




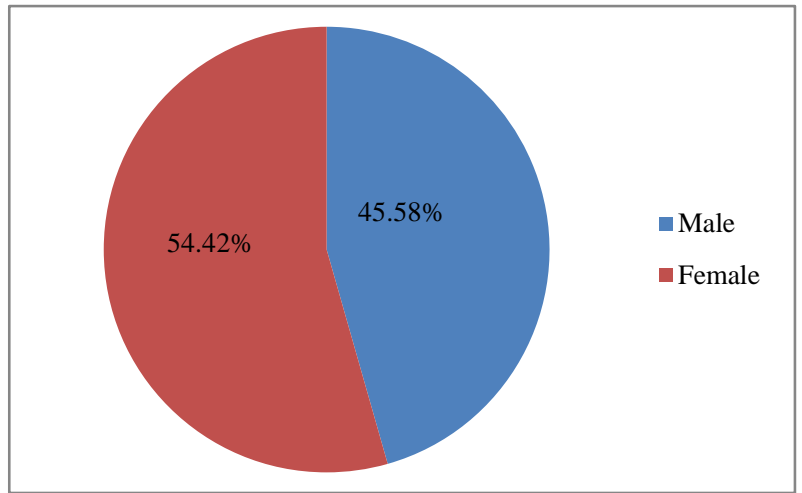

Figure 1. Graphical representation of distribution of respondent by gender.

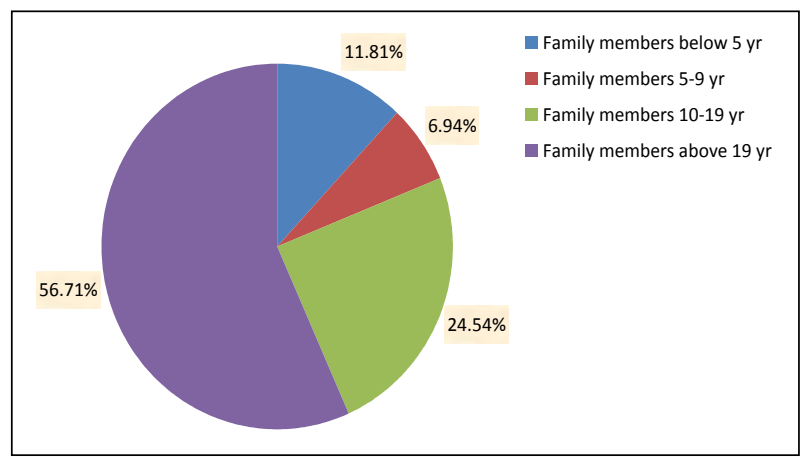

Figure 2. Graphical representation of distribution of respondent by age group.

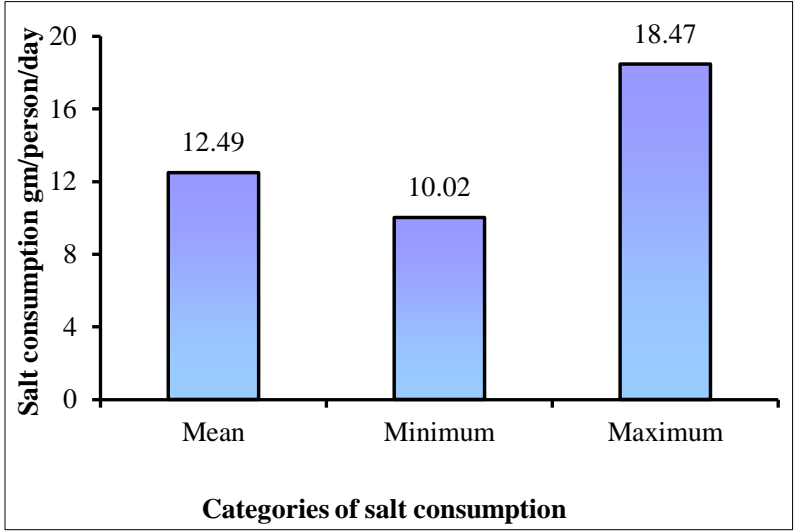

Figure 3. Graphical representations of Salt consumption g/person/day.

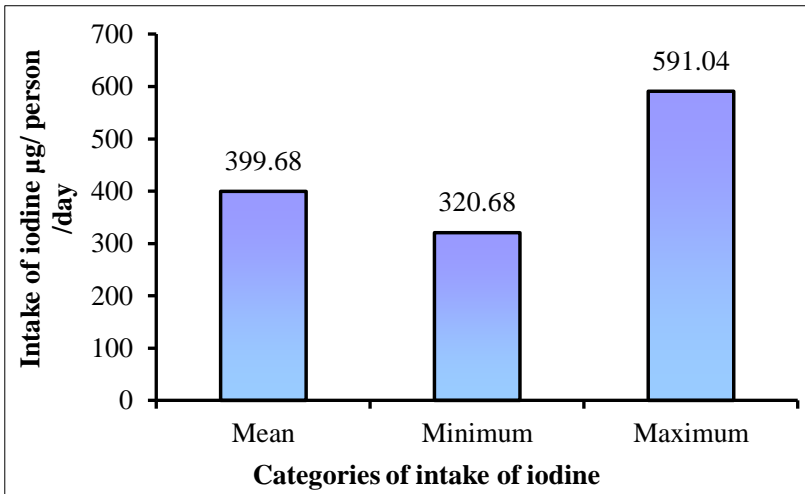

Figure 4. Graphical representation of Intake of iodine $\mu \mathrm{g} / \mathrm{person} / \mathrm{day}$. 
4. Discussion

\subsection{Physico-chemical analysis of iodized salt}

By observation, amount of moisture content was $0.18 \%$ in iodized salt, which is compared with BDS standard, WFP standard, China standard and India standard is $6 \%, 3 \%, 0.1 \%$ and $0.5 \%$ respectively. This is nearly to present study. High moisture content is important factor affecting the quality of product (Akubor, 1996). Product having high moisture content has minimum self-life (Ayub, 2005). In iodized salt, amount of Water insoluble matter percent by mass was found $0.11 \%$, which is compared with BDS, WFP, China, and India standard is $0.1 \%, 0.2 \%, 0.1 \%$ and $0.1 \%$ respectively. Observation values are satisfactory according to standard reference value of BDS, WFP, China, and India. By observation, amount of Chloride content (as $\mathrm{NaCl}) \%$ in iodized salt was found $99.55 \%$ which is compared with BDS, WFP, China, and India standard 97\%, 97\%, 99\% and $98.50 \%$ respectively. Observation value supports the reference value. $\mathrm{pH}$ is one of the important characteristics which means the negative logarithm of hydrogen ion concentration in a solution. $\mathrm{pH}$ of the samples obtained by analysis with 7.26, in BDS standard it is ranges 6.4-7.4, in WFP it varies 6.5-7.2, in China and India it is ranges 6.5-7.4 and 6.6-7.2 respectively. $\mathrm{pH}$ of the samples obtained by analysis within the range set by BDS, WFP, China, and India. Iodine is one of the essential micronutrients required for the normal mental and physical well being of human beings. The healthy human adult body contains $15-20 \mathrm{mg}$ of Iodine of which $50-80$ percent is in the thyroid gland, which weighs only $15-25 \mathrm{gm}$. The tiny quantity of iodine is required everyday in the thyroid gland for adequate production of the hormone thyroxin. It requires four atoms of Iodine to make one molecule of thyroxin. Iodine content of the samples obtained by analysis was $32 \mathrm{mg} / \mathrm{kg}$, in BDS, WFP, China standard it varies $20.0-50.0 \mathrm{mg} / \mathrm{kg}$ and India standard it is $30 \mathrm{mg} / \mathrm{kg}$. Observation value is within the range set by BDS, WFP, China, and India. $\mathrm{Mg}$ and $\mathrm{Ca}$ content of iodized Salt samples were obtained by analysis was $0.00 \%$ and $0.1 \%$ respectively which is within the range set by BDS, WFP, China, and India.

\subsection{Salt intake survey}

In this study, among the family members $45.58 \%$ were male salt consumers and $54.42 \%$ were female consumers. Study was done among 68 families for a period of 35 days. Family member was divided into 4 groups according to their age - below 5 years, 5-9 years, 10-19 years and above 19 years. Family members below 5 yr was $11.81 \%$, in family members $5-9$ yrs it was $6.94 \%$, Percentage of salt consumer in Family members 10-19 yrs was $24.54 \%$, and salt consumer \% in family members above 19 yrs was $56.71 \%$. By statistical analysis among data, finding of study that, the mean value of Salt consumption $\mathrm{g} / \mathrm{person} / \mathrm{day}$ was 12.49, minimum Salt consumption g/person/day among members was 10.02 and maximum salt consumption was $18.47 \mathrm{~g} /$ person/day among the family members. Intake of iodine, in case of family members, the mean value was $399.68 \mu \mathrm{g} /$ person/day, minimum intake of iodine was $320.68 \mu \mathrm{g} / \mathrm{person} /$ day and maximum intake of iodine was $591.04 \mu \mathrm{g} /$ person/day among the family members. The daily Dietary Reference Intake recommended by the United States Institute of Medicine is between 110 and $130 \mu \mathrm{g}$ for infants up to 12 months, $90 \mu \mathrm{g}$ for children up to eight years, $130 \mu \mathrm{g}$ for children up to 13 years, $150 \mu \mathrm{g}$ for adults, $220 \mu \mathrm{g}$ for pregnant women and $290 \mu \mathrm{g}$ for lactating mothers, (Institute of Medicine, 2004). The Tolerable Upper Intake Level (UL) for adults is $1,100 \mu \mathrm{g} /$ day $(1.1 \mathrm{mg} /$ day) (USNRC, 2000). As of 2000, the median intake of iodine from food in the United States was 240 to $300 \mu \mathrm{g} / \mathrm{day}$ for men and 190 to $210 \mu \mathrm{g} /$ day for women (USNRC, 2000). Observed value support the reference value.

\section{Conclusions}

According to the results obtained from chemical analysis of salt samples, these may be recommended as safe for consumption. By iodine intake survey, finding of study is that, iodine intake by individual in village Chamuria in Tangail district is adequate to avoid IDD in normal health condition. Salt consumption among the villagers was minimum $10.02 \mathrm{~g} / \mathrm{person} /$ day and maximum was $18.47 \mathrm{~g} / \mathrm{person} /$ day. Intake of iodine among the villagers minimum was $320.68 \mu \mathrm{g} /$ person/day and maximum was $591.04 \mu \mathrm{g} / \mathrm{person} /$ day. By iodine intake survey, finding of study is that, intake of iodine by individual in village chamuria in tangail district is adequate to avoid IDD in normal health condition. The study shows that, consumption rate is satisfactory to fulfill the daily requirement of iodine intake. If we enhance the regular intake of salt at an acceptable label, then it is possible to alleviate prevailing micronutrient deficiency problem from Bangladesh. 


\section{Acknowledgements}

The author acknowledge with thanks for the financial assistance received from the project entitled -"Estimating stability of iodine in different types of iodized salt used for human consumption in Bangladesh" funded by the Micronutrient Initiative, Ottawa, Ontario, Canada.

\section{Conflict of interest}

None to declare.

\section{References}

Abraham GE, 2006. The history of iodine in medicine. International J. of Food Research, 15:325-330.

Akubor PI, 1996. Department of Food Technology, Federal Polytechnic. J. of Plant Fruits for Human Nutrition, 49:213-219.

AOAC, 2005. Association of Official Analytical Chemists, Official Methods of Analysis, $18^{\text {th }}$ edition, Arlington, Virginia, USA.

AOAC, 2005. Association of Official Analytical Chemists, Official Methods of Analysis, $4^{\text {th }}$ edition, Washington DC, USA.

Ayub MA, ZEB Ullah and MAK Kattak, 2005. Effect of various sweeteners on chemical composition of guava slices. Sarhad Journal of Agriculture, 21:131- 134.

Bangladesh Gazette, 1989. Iodine Deficiency Disease Prevention Act.

Diosady LL, JO Alberti, MMG Venkatesh and GS Fitz, 1998. Stability of Iodine in iodized salt used for the correction of iodine deficiency II. Food and Nutrition Bulletin, 19:240-250.

Edmundson WC and AE Stella,1999. Goitre in Asia, Report of a Seminar on Goitre Control, New Delhi, WHO, SEATO.

EFSA, 2006. Opinion of the Scientific Panel on Additives and Products or Substances used in Animal Feed on the request from the Commission on the use of iodine in feeding stuffs. Journal of EFSA, 384:1-9.

FAO/WHO, 2001. Food and Agricultural Organization and World Health Organization of the United Nations, Human Vitamin and Mineral Requirements 12 Bangkok, Thailand.

IOM, 2004. Institute of Medicine, Dietary Reference Intakes for Vitamin A, Vitamin K, Arsenic, Boron, Chromium, Copper, Iodine, Iron, Manganese, Molybdenum, Nickel, Silicon, Vanadium, and Zinc, National Academy Press, Washington, DC. pp. 442-501.

USNRC, 2000. United States National Research Council, Dietary Reference Intakes for Vitamin A, Vitamin K, Arsenic, Boron, Chromium, Copper, Iodine, Iron, Manganese, Molybdenum, Nickel, Silicon, Vanadium, and Zinc, National Academies Press, USA. pp. 258-259.

Venkatesh MMG, 1987. In: Hetzel BS, Dunn JT, Stanbury JB (Editors), The prevention and control of iodine deficiency disorders, Amsterdam, The Netherlands. pp. 111-125.

WHO, 2001. World Health Organization, Iodine and Health: eliminating iodine deficiency disorders safely through salt iodization, WHO, Geneva. 